This is an electronic reprint of the original article. This reprint may differ from the original in pagination and typographic detail.

Author(s): Mättö, Toni; Sippola, Kari

Title: $\quad$ Cost Management in the Public Sector : Legitimation Behaviour and Relevant Decision Making

Year: $\quad 2016$

Version:

Please cite the original version:

Mättö, T., \& Sippola, K. (2016). Cost Management in the Public Sector : Legitimation Behaviour and Relevant Decision Making. Financial Accountability and Management, 32(2), 179-201. https://doi.org/10.1111/faam.12085

All material supplied via JYX is protected by copyright and other intellectual property rights, and duplication or sale of all or part of any of the repository collections is not permitted, except that material may be duplicated by you for your research use or educational purposes in electronic or print form. You must obtain permission for any other use. Electronic or print copies may not be offered, whether for sale or otherwise to anyone who is not an authorised user. 


\title{
COST MANAGEMENT IN THE PUBLIC SECTOR: LEGITIMATION BEHAVIOUR AND RELEVANT DECISION MAKING
}

\author{
RUNNING TITLE: \\ LEGITIMATION BEHAVIOUR AND DECISION MAKING
}

\author{
Toni Mättö (PhD)* \\ Post-Doctoral Researcher \\ Jyväskylä University School of Business and Economics \\ toni.m.matto@jyu.fi \\ Kari Sippola $(\mathrm{PhD})$ \\ Post-Doctoral Researcher \\ Jyväskylä University School of Business and Economics \\ kari.sippola@jyu.fi
}

\footnotetext{
*Address for correspondence: Toni Mättö, Jyväskylä University School of Business and Economics. Jyväskylä, P.O. Box 35, 40014. E-mail: toni.m.matto@jyu.fi
}

\begin{abstract}
We gratefully acknowledge the helpful and essential comments we received from two anonymous reviewers. We also thank Professor Marko Järvenpää for his help. We wish to thank the Foundation for Economic Education for funding this research project. We are appreciative of the helpful comments we received from our colleagues at the Jyväskylä University School of Business and Economics. Many thanks as well for the feedback we received at the Annual Congress of the European Accounting Association 2013, Paris, and at the 9th European Network for Research in Organisational \& Accounting Change (ENROAC) 2013, Jyväskylä.
\end{abstract}




\title{
COST MANAGEMENT IN THE PUBLIC SECTOR: LEGITIMATION BEHAVIOUR AND RELEVANT DECISION MAKING
}

\begin{abstract}
This paper presents a case study where a cost management project was implemented using action research methodology at two Finnish organizations working in a purchaserprovider relationship. While the study demonstrates the efficiency-seeking motive behind the implementation of the management accounting tool, subsequent investigation found that tool remained partly unused despite showing its potential relevance for practice through user involvement. However, this does not necessarily signal legitimation-seeking behaviour. Reasons for not using some parts of the tool point to an overestimation of the functionality and an underestimation of implementation problems during the design process. The case also highlights the relationship between relevance and decision making.
\end{abstract}

\section{Keywords}

Relevance, legitimation, public sector, cost management 


\section{Introduction}

Discussion on the state of public sector management accounting research (PSMAR) has been lively for some years. Several researchers have found that public sector organizations tend to initiate cost management changes in order to increase their legitimacy (Brignall and Modell 2000, Verbeeten 2011, Carvalho et al. 2012) or imitate other organizations that are deemed advanced (Johansson and Siverbo 2009a). Thus, the impact of recent cost management changes on actual decision making remains small according to these studies.

Another frequently expressed concern in PSMAR is the relevance of the current research for practitioners (Van Helden and Northcott 2010). Several authors have expressed concerns that recent literature on PSMAR has only limited practical orientation (Hitt 2005, Rynes and Shapiro 2005). Regarding Management accounting (MA) research in general, Malmi and Granlund (2009) and Van Helden (2005) have also expressed similar views.

Additionally, in his recent literature review on institutional research in the public sector accounting literature, Modell (2009) notes that very few studies address the intertwined nature of efficiency-seeking reasons and legitimation-seeking behaviour that explains the form of management accounting (and more precisely, the performance measurement and management) in public sector organizations. The present discussion merely evaluates the strengths and shortcomings of different approaches. 
The study by Ter Bogt (2008) found traces of discontent towards accounting and control changes being expressed in public organizations. Although the interviewees in his study indicated efficiency-seeking to be a very important reason behind the accounting changes implemented in their environment, the actual outcome was in many cases not as practical as had been hoped.

In addition, Adolfsson and Wikström (2007) found mixed results; their case study on the Swedish schooling system reported some of the participants were unhappy about a quality system that did not include cost management as part of the implementation and hence did not address their economic concerns. This might be another example of a case that fuels the thought behind legitimation-driven behaviour in the public sector. However, we might ask whether it is the public sector that is at fault for this apparent lack of efficiency seeking or whether the tools used have not been capable of addressing the relevant economic concerns.

We suggest that there might be a connection between the perceived lack of efficiency seeking, as evidenced by the lack of decision making, the notion of legitimation-seeking behaviour, and the reported lack of relevance in recent studies. This study employs a case study to illustrate that providing information relevant to practitioners by addressing economic concerns with cost management bridges the gap between theory and practice. 
This paper responds to calls for more examples of cost management in the public sector (Verbeeten 2011) and provides an example case of a cost management initiative with actual usage of the information for economic decision making. In this study, a cost management tool with a quality emphasis previously used in private organizations is introduced to a case setting with two public sector organizations working within a purchaser-provider model. Therefore, this research addresses recent concerns that research is becoming more detached from practical issues and actual decision making.

The remainder of the paper is organized as follows. The next section presents the discussion around relevance and legitimation-seeking behaviour in the public sector. The third section discusses cost management and quality costing, while the fourth section describes the methodology of, and main choices made in, this research. The fifth section describes the case study, and the sixth section presents the main findings of the paper and discusses the insights arising from them.

\section{Practical relevance and legitimation-seeking behaviour}

The new public management (NPM) has been characterized as involving a restructuring of public services towards decentralization and corporatization; adopting a new management focus; the introduction of markets or quasi-markets for public services; the rationalization of public services; and a focus on quantification to deliver efficiency gains (Lapsley 1999). One important feature of NPM is the adoption of private sector management styles and techniques in the public sector (Hood 1995). Ter Bogt (2008) 
notes, however, that there seems to be some discontent over present cost management techniques in the public sector. Furthermore, he argues that NPM has not realized its functional potential in that sector. Along these lines, there are research results that seem to indicate legitimation-seeking behaviour in public sector organizations (Brignall and Modell 2000, Verbeeten 2011, Carvalho et al. 2012).

Organizational legitimacy has been studied extensively from both strategic (Dowling and Pfeffer 1975, Ashforth and Gibbs 1990) and institutional perspectives (DiMaggio and Powell 1983, Meyer and Rowan 1991). The strategic perspective has focused on a managerial approach whereby organizations strive to gain societal support by manipulating their environment. In contrast, the institutional perspective has focused more on sector-wide dynamics where cultural pressures surpass organizational controls; that is, the focus is directed more towards the societal influence on the organization rather than the organization's activities. Suchman (1995, p. 574) offers a general definition of legitimacy as 'a generalized perception or assumption that the actions of an entity are desirable, proper, or appropriate within some socially constructed system of norms, values, beliefs, and definitions'. The adoption of models, standards, and certifications to increase organizational legitimacy is termed cognitive legitimacy by Suchman.

Institutional theory has recognized that there are no simple distinctions between institutionally grounded, legitimacy-seeking behaviour and efficiency-centred rational choice (Modell 2009). Recent works have shown that the reasons for efficiency-seeking action may not conflict with the value systems associated with legitimation (Lawrence 
and Suddaby 2006, Lounsbury 2007). For example, Järvinen (2006) notes that cognitive legitimation-seeking behaviour and efficiency-seeking through decision making are not always mutually exclusive. An organization may strive to legitimize itself in front of external stakeholders while simultaneously seeking efficiency gains from new cost management techniques. Oliver (1991) labelled such reasons for adopting a cost management technique institutional and economic fitness reasons. However, as noted by Modell (2009), studies have not progressed beyond acknowledging this joint effect and have consequently failed to analyse the relationship between symbolic action and the efficiency-seeking rational choice (p. 286). The literature has failed to address the relationships between economic concerns evidenced through rational decision making, legitimation-seeking behaviour, and the decision-relevance of an MA tool.

However, as mentioned above, we suggest that there might be a misunderstood relationship between the decision-relevance of the outcomes generated by a given MA technique and the efficiency-seeking and legitimation-seeking rationales attached to it. Although both rationales may coexist and influence the adoption of a cost management system, the lack of any discernible action may be falsely interpreted as legitimationseeking behaviour in certain cases. Thus, the relationship between these influences may be even more complex than is evident from the literature. Our focus in this study is to understand the complex relationship between the decision-making use of the different outcomes resulting from the implementation of a MA technique, their perceived relevance and the efficiency-seeking rationales attached to them. 
Nicolai and Seidl (2010) differentiate three forms of relevance based on their extensive review of the literature: instrumental, conceptual, and 'legitimative' relevance. While the first two are associated with relevance to decision making, the last classification is a suggestion that even legitimizing behaviour may be relevant. In this case, a given piece of knowledge is adopted in an organization to legitimate a chosen course of action in relation to oneself and others. Although Nicolai and Seidl (2010) call all of these forms of relevance different aspects of 'practical' relevance, for us, practical relevance is associated more with the first two types noted above, that is, with instrumental and conceptual relevance. Of these, instrumental relevance means that new knowledge influences the decision-making situation, while conceptual relevance is knowledge about the decision-making situation itself. Thus, the latter answers the question 'What choices do we have?', whereas the former answers the question 'What are the consequences of the specific course of action?'

Although the legitimation of a chosen course of action may be relevant for the organization, in our view, practical relevance refers to a practitioner's ex post evaluation of the information acquired. For information to be of practical relevance, it must influence practice. Legitimation behaviour, on the other hand, is concerned with adopting a technique with an ex ante goal of legitimating one's position in relation to others with little or no regard for the actual influence of the acquired information on the decision making. However, the adoption of a technique may be relevant for an organization in the process of legitimizing itself to outside stakeholders, for example, in an effort to secure 
future funding from a governmental agency. We might term this legitimative relevance as a type of strategic relevance aligned with the strategic school of research on legitimacy.

Carvalho et al. (2012) find evidence that public organizations only legitimize their actions through the adoption of new cost management techniques, rather than using them to make decisions, but suggest qualitative studies would be necessary to confirm that notion. In addition, Verbeeten (2011) studied the adoption of cost management techniques in the public sector in the Netherlands, which is a similarly NPM-oriented country to Finland. These countries share the same style of public sector management with a focus on meeting the citizens' needs and a tradition of negotiation and consultation. Verbeeten's findings are in line with Carvalho et al. (2012) who found that cost management systems are mainly used to satisfy regulatory demands and to legitimize an organization before external stakeholders.

Johansson and Siverbo (2009a, 2009b) differentiate between the adoption of public sector management techniques and their actual use. This approach shares some features of the cost management project success evaluation criteria offered by Anderson and Young (1999) as well as Malmi (1997). These authors used both a quantitative study (Anderson and Young 1999) and a qualitative case study (Malmi 1997) and recognized that for a cost management project to be successful, the project needs to produce new data, and that data must be acted upon. 
The generation of new data through an MA technique and the possible resulting action are central to our study; a technique may be adopted in the organization, but if the manager deems the data generated by the technique to be irrelevant to the organization, it may prompt a decision not to use the technique or the resulting data. We hypothesize that in this situation it may appear that the reasons behind the adoption of the technique are more attributable to legitimation-seeking behaviour than to efficiency-seeking or practical decision making. Johansson and Siverbo (2009a) write of various possible explanations for the observed adoption of a technique that is not subsequently used. First, they suggest that political decisions resulting in the adoption of a technique may not result in actual use at the daily administrative level because of the different goals of the stakeholders. Second, they record the possible legitimation behaviour and imitation behaviour provided in the literature (Brignall and Modell 2000, Johansson and Siverbo 2009a, Verbeeten 2011, Carvalho et al. 2012). Third, they suggest that organizations may lack the funds or capacity to use the adopted technique. However, we argue that the technique must first be deemed relevant to the organization before it will be considered for use after the adoption decision. Although unforeseen events or a lack of resources may prevent the use of the technique, the notion of apparent legitimation behaviour or imitation behaviour may in some cases be the result of an interpretation made by researchers. This interpretation comes from the lack of any real actions or decisions based on the information provided by the technique, while in reality, the practitioner may simply not perceive the information to be relevant. 
Next, we briefly sum up our theoretical arguments; we observe in the recent discussions the wealth of studies that seem to indicate legitimacy-seeking behaviour to be the main driving force in public sector cost management implementations (see Brignall and Modell 2000, Verbeeten 2011, Carvalho et al. 2012).

We acknowledge that efficiency-seeking behaviour and the attainment of symbolic legitimacy may well coexist and be intertwined (Järvinen 2006, Lawrence and Suddaby 2006, Lounsbury 2007, Modell 2009), but caution against judging an observed lack of post-adoption use of an MA technique to be merely legitimacy-seeking behaviour. This is because the data and outcomes generated by the technique may lack decision-relevance for the decision maker.

\section{Cost management}

Cost management can be defined as the application of MA concepts, methods of data collection, analysis, and presentation in order to provide the information needed to plan, monitor, and control costs (CIMA, 2005). Cost management systems are helpful in underpinning decision making and informing the viability and coherence of activities (see McChelry et al. 2007).

Cost of poor quality (COPQ) has been defined by Juran (1989) as the sum of those costs that would vanish if there were no quality problems while Crosby (1979) differentiated between the cost of conformance and the cost of non-conformance. Schiffauerova and 
Thomson (2006) write of measuring quality costs: lower costs can only be achieved if quality costs are identified and measured. Analysis of the organization's COPQ also serves as a link between improvement actions, the costs associated with them, and customer expectations. This can be seen as the coupling of reduced costs and increased benefits (Schiffauerova and Thomson 2006). Identification and measurement of quality costs is achieved through data collection, analysis, and presentation. Therefore, quality costing can be seen as a part of cost management (see CIMA 2005).

Despite advances in quality management and systems, most managers still find it difficult to link quality-development projects with expected economic returns (Ittner and Larcker 1996). Ittner (1999) considers the primary reason to be the lack of adequate methods for determining the financial consequences of poor quality. This is, for us, yet another example of the practitioner's perception of the lack of decision-relevance. The topic of quality, as well as the measurement of quality and quality costs (QC) has been touched upon in the MA literature (Atkinson et al. 1994, Ansari et al. 1997, Horngren et al. 2009).

\section{Methodology}

The interventionist research (IR) allows for the researcher's active, participative cooperation with the actors in the field. In addition to adding to our theoretical understanding, IR projects tend to have practical purposes as well, in that there is often a strong desire to change the status quo in some way (Lukka 2005). Lukka argues that IR aims to narrow the gap between practice and academic theory. Interventionist researchers 
enter organizations not just to observe or collect data (see e.g. Arnaboldi 2013) but also to offer solutions to organizational problems. They are seen as important mediators between academia and practice (Van Helden et al. 2010).

There has recently been a renewed interest in the IR methodology as used in the fields of accounting and management (Baard 2010). The interventionist tradition encompasses the constructivist research approach (see e.g. Kasanen et al. 1993, Labro and Tuomela 2003, Malmi et al. 2004, Labro et al. 2005, Lukka 2007), action science (Argyris et al. 1985), design science (Van Aken 2004), clinical research (Schein 1993), and innovation action research (Kaplan 1998), as well as action research (AR) (see e.g. Jönsson and Lukka 2005, Baard 2010). AR was initiated by Lewin (1946). It is also considered to be the origin of all IR in the social sciences (Jönsson and Lukka 2007). The volume of literature on AR is considerable (see Baard 2010 for a more detailed review). According to Ter Bogt and Van Helden (2011), AR is probably the best-known stream of IR. Our approach to implementing the technique described in Malmi et al. (2004) is to use an interventionist study with action research to facilitate the implementation of this technique in the public sector context. Our case consists of two Finnish organizations working within a purchaser-provider relationship.

IR is needed in this study to produce directly applicable results (see e.g. Malmi and Granlund 2009). Simply observing organizational life, would not have led to the implementation of the cost management method and no conclusions on the decisionrelevance, efficiency rationales, or the legitimacy-related relevance of the outcomes could 
be drawn. The researcher therefore needed to introduce the method in order to generate outcomes in the organizations.

An article on quality costing (Malmi et al. 2004) follows the constructive approach suggested by Kasanen et al. (1993), considering the practice-relevant problem of managers having to justify investments in quality improvement (Ittner and Larcker 1996; Ittner, 1999; cf. Kasanen et al. 1993). The construct by Malmi et al. (2004)—a collaborative approach for managing the project cost of poor quality (CAMP)—provides an indication of expected cost savings or expected reductions in resource consumption given that certain poor quality cost elements can be removed or the required proactive solutions are successful (Malmi et al. p.314). In this paper, that construct developed by Malmi et al. (2004) is used in two public sector organizations exemplifying a purchaserprovider relationship.

Findings by Hoozee and Bruggerman (2010) indicate that for the cost management method to produce operational improvements, it requires the participation of the workforce. One feature of the quality costing method applied in this study is the bottomup perspective, which involves shop-floor workers from the start. In our case, the questionnaire was sent to 40 employees of the purchaser and of the producer. The workers were tasked with identifying their operational work-related problems for further analysis. 
The CAMP method (Malmi et al. 2004) focuses on quality failure costs, rather than the entire (COPQ). Several studies have shown that failure costs are generally the highestquality cost class in an organization (see e.g., Gryna et al. 2007, Seokhin and Nakhai 2008) whether the organization is public or private.

The CAMP method starts from an initial survey where respondents are asked to indicate problems in their work environment. They are also asked to estimate the impact of those problems on their everyday work and finally to offer opinions on what caused them.

We used the survey responses to draw fishbone diagrams (Ishikawa 1985) to represent cause-and-effect chains for root cause analysis. These so-called root causes (Ishikawa 1985) of the problems were identified from the diagrams so that the actual causes of the problems could be eliminated. The method described here increases the validity of the results by feeding the constructed presentations back to the organization's members. This is achieved by conducting mutual workshops that place members of the organization into teams. These teams are then given the fishbone diagrams for possible modification or addition.

The CAMP method addresses efficiency-seeking concerns by assigning QC to identified problems. This is done by expert evaluation conducted by organizational members with good knowledge of the processes involved. Identified problems are evaluated for their cost impacts in a specific workshop where relevant costs are evaluated through working hours lost, equipment or material costs and so forth. 
The method also increases validity by using multiple data sources; the data are gathered through an initial survey, workshop materials, and observation during workshop meetings. The increased validity obtained by using multiple sources is discussed extensively in the literature (Morgan and Smircich 1980, Eisenhardt 1989). The literature also addresses using quantitative methods to complement qualitative ones (Morgan and Smircich 1980, Modell 2005). These calls for data triangulation, as well as method triangulation, are addressed by the use of the CAMP method; methodical triangulation is achieved by using a Pareto graph (Ishikawa 1985) to quantify problems through the classes they represent. For example, problems concerning resource use or the lack of resources can be classified under the resources problem class. The size of the classes is then calculated by the number of problems they contain (Figure 1). Qualitative analysis is achieved by constructing the fishbone diagrams, which encapsulate the answers obtained through the initial survey in cause-and-effect chains (Appendix).

There are many studies of the role of consultants in public sector organizations (see e.g. Hood 1995, Lapsley and Oldfield 2001, Van Helden and Northcott 2010, Van Helden et al. 2010, Ter Bogt and Van Helden 2011, Arnaboldi 2013). Westbrook (1995) identifies five basic differences between consulting and action-type research; the role of theory development, the reporting of failed implementations, the presentation of sufficient context, the attainment of new knowledge and the charging of fees. Furthermore, Mouritsen et al. (2002) point out the researchers' knowledge advantage over consultants 
and other tradesmen: being critical. Researchers reflect on the conditions of the knowledge they produce and on the validity of their propositions.

This study observes the wealth of PSMAR studies that argue the legitimation-seeking as being a primary driving force behind public sector cost management initiatives (Brignall and Modell 2000, Verbeeten 2011, Carvalho et al. 2012). To address these arguments, this study sheds light on the complex relationship between the decision-making use of different outcomes from the MA technique, the perceived relevance of these outcomes, and the efficiency-seeking rationale behind MA tool implementation. The method of data collection is taken from the MA literature (Malmi et al. 2004), and the data obtained with this method are subsequently reflected on in the aforementioned discussion. The researcher acts as an observer following the introduction of the working methods for each phase. The follow-up work for this study indicates that although most of the improvement initiatives generated were carried out, the metrics formulated in this study were largely not adopted. Thus, this study provides at least some applicable solutions, while simultaneously attempting to contribute to the aforementioned discussion on the effects of decision-relevance on different rationales, that is, legitimation-seeking and efficiencyseeking behaviour.

\section{The case}

The Finnish public sector is undergoing a series of developments. In the society as a whole, municipalities and their service structures are being reformulated. This process is 
taking place because many municipalities can no longer produce their services in the way they used to. The volume of tasks and required services has increased, while available resources are being reduced. Some reasons for this development have been identified (Kallio et al. 2006) and include changes in the Finnish population structure; society's enhanced responsibility for individuals; and more demanding consumers, to name but a few. These developments have focused the attention of the public sector on improvement projects, the main target of which is to be more efficient.

Our single-case study consists of two organizations, A and B, working in a purchaserprovider relationship. The municipality in which our case is situated had issued a directive to identify savings and efficiency gains wherever possible. In addition, one of the researchers had had prior contact with Organization A, having worked on an unrelated research project with it in early 2007 . These were both favourable conditions for the project's start-up negotiations. The researcher presented the idea of a mutual quality cost management project to both organizations, initially separately. When both organizations showed interest in cutting costs through the proposed measures, the researcher presented the project idea at a joint meeting in late September 2007. After the project had been sanctioned, a start-up meeting was held in October 2007, at which the initial survey was arranged for late October.

Organizations $\mathrm{A}$ and $\mathrm{B}$ focus on the provision of public street and park maintenance, which in Finland is financed through taxation. The purchaser-provider model (PPM) is the governing structure for the provision of these services in our focus city. PPM itself 
has four different actors and functions: the purchaser, the producer, end users, and the principal or financier, which is usually the municipality. The purchaser evaluates, organizes tenders, and places orders. The purchaser then enforces the fulfilment of contracts that it has made with different producers. The producer may be a public organization whose resources are provided by the municipality or a private organization run for profit. Moll and Hoque (2008) refer to these as internal and external providers. Producers and purchasers are independent entities within PPM and have their own decision-making power, although the municipality ultimately governs public organizations. The end user is a citizen, client, or patient, depending on the setting and context. For more details about the PPM context in Finland, see for example Hyvönen and Järvinen (2006) and Mättö (2012).

Organizations A and B are located in a medium-sized Finnish city. Organization A is a part of the city's urban design and city planning department. Its areas of responsibility are the city streets, parks, harbour, outdoor lighting, garbage disposal, and monitoring parking. Organization A buys the services related to street and park construction and maintenance from Organization B. Organization A's annual budget for street and park maintenance in 2007 was approximately 30 million euros, and it employed around 30 employees at the time. Those employees handled the administrative work for street and park maintenance, various service purchases, and street monitoring.

Organization B provides construction and maintenance services for streets and park areas, including the planting and placement of flowerbeds and trees in the parks. It also offers 
land and depth measurement services. Organization A is its main customer, but it also has private customers, particularly for its land and depth measurement services. Organization B had about 200 employees in 2007, along with approximately 100 temporary employees in the summer. Its annual turnover was slightly below 20 million euros in 2007.

\subsection{Case description}

Project work for the case with Organizations A and B started in late 2007. The results anticipated included knowledge of quality problems in the shared work processes, possible solutions for them, and costs attributed to problems. It was also agreed that the organizations would brainstorm metrics in the last workshop to create potential means for tracking the results of the project.

The project was forecast to take about six months, with eight employees participating from each organization until the project reached the stage of holding the metrics construction workshop. In this phase, middle-level managers and the CEOs from both sides, totalling eight people, would prioritize improvement ideas, and construct the associated metrics.

The expected results were tied to work phases, starting from the initial survey being emailed to selected participants from both organizations. These participants were selected by the organizations themselves. The project was carried out with both organizations' participants taking part in the workshops and surveys at the same time to create data from 
the mutual work processes of the two organizations. This method made it possible to facilitate discussions between both sides of the PPM to identify existing problems between the organizations and to create solutions with purchaser and producer working together. Questions in the initial survey were constructed by the researcher to reflect the data-gathering methods that were presented in the Malmi et al. (2004) study. As such, the aim of the questionnaire was to find cause-and-effect relationships for the problems identified in the survey (see Ishikawa 1985, Malmi et al. 2004). The questionnaire included questions on the issues respondents encountered in their everyday work and their estimation of the consequence of any given issue, as well as its possible causes.

To enhance the volume of data, the survey was sent to 12 additional people from each organization in addition to the 16 participants already selected. Of the 40 questionnaires sent, the purchasing organization returned 13 , and the provider returned 12 , totalling 25 responses. These answers were rich in data, containing 52 different problems analysed with a cause-and-effect diagram for the producing side, and 41 different problems analysed with a cause-and-effect diagram for the purchasing side, totalling 93 different cause-and-effect lines. From these answers, the researcher constructed a fishbone diagram presentation for the project (see Appendix for an example).

Examination of all the different problems expressed in the questionnaire answers identified seven different classes in terms of different areas to which they were related (Figure 1). These classes encapsulated issues dealing with the lack or the use of resources; of mutual trust between the purchaser and the producer; with cooperation between PPM 
organizations; related to mutual contracts concerning the work purchased and produced; to lack of time or with scheduling; those related to information; and finally, to issues generating extra work. These classes were labelled resources, trust, cooperation, contracts, time, information, and extra work.

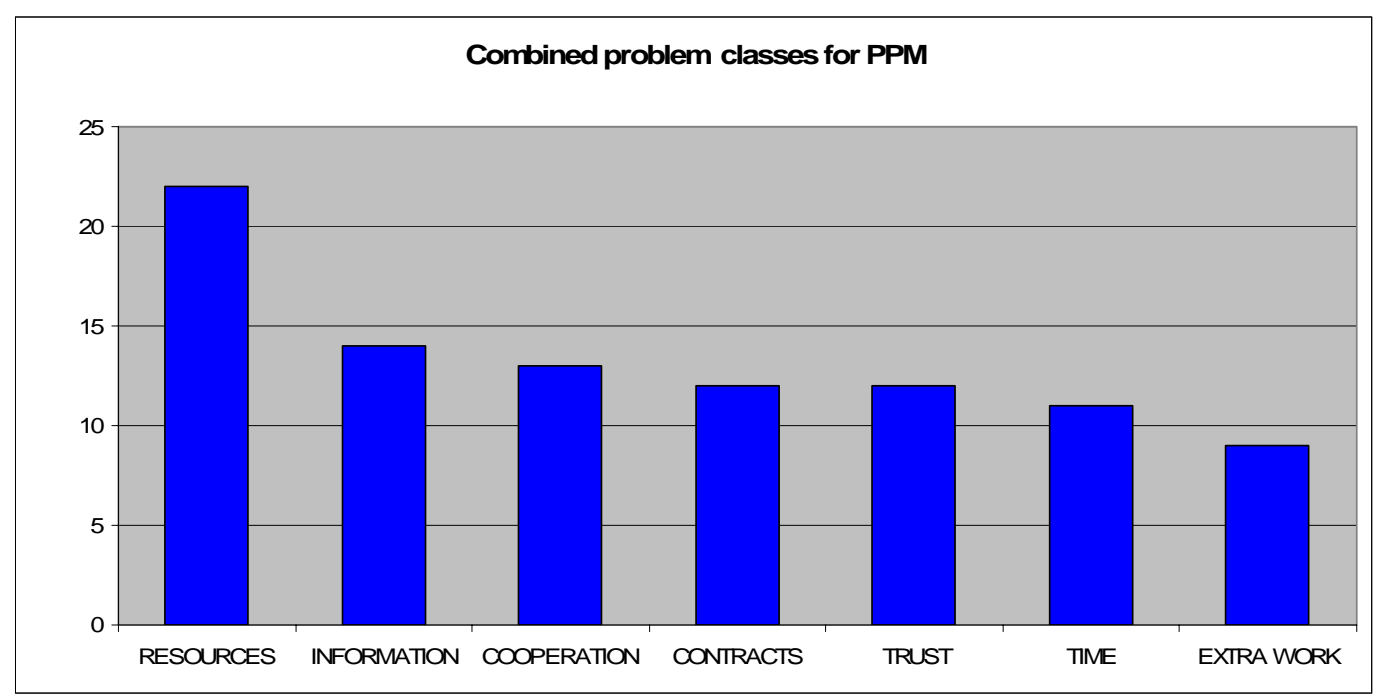

Figure 1. Problem classes for the purchaser-provider project

\subsection{First workshop}

The problem class Pareto (Figure 1) and fishbone diagrams (Appendix) were taken to the first workshop, which included the participants from both organizations. All the participants and the management on both sides of the PPM had received the preliminary fishbone data in advance to reduce the time required for familiarization with the data in the actual workshop. 
All 16 expected participants attended the first workshop day. Participants were divided into three teams with five or six members gathered from both sides of the PPM working with designated parts of the fishbone data to forestall parallel work. The purpose of the workshop was to go through the fishbone diagrams and validate the researcher's presentation. Where necessary, teams could change or enrich the diagrams. While the teams were working on the data, the researcher spent time observing the team discussions.

After the team discussions, the teams presented their findings to all the participants for a mutual discussion. During this closing discussion, as well as in the presentations, it became clear that problems dealing with information flow and resources were the main areas of interest for both sides of the PPM.

After the presentations, the researcher collected the presentations for transcription. Afterwards, the researcher sent the modified fishbone diagrams and the highlighted problem areas to the participants, as well as to the management on both sides of the PPM, for review and feedback.

\subsection{Second workshop and improvement projects in the case}

The second workshop for the research project was held in the middle of February 2008, about a month after the first one. Presentations and diagrams from the first workshop had been sent for review to all the participants, and they had the option of adding their 
thoughts and comments between the workshops. As no additional comments were received, this material formed the basis for the second workshop.

The same 16 participants from the first workshop took part in the second workshop. The aim of this workshop was to review all the material gathered so far and construct improvement ideas as solutions for important problem issues. The materials included the fishbone diagrams from the first workshop and the problem class Pareto graph. As in the first workshop, the teams were divided into three different teams, with both PPM sides present on each team, leading to five to six members on each team. Fishbone diagrams were divided among different teams in such a way as to avoid parallel working. For example, one team received the diagrams labelled resources and time, while another received trust and information. Teams were able to choose which problems they would address, and were expected to develop several improvement ideas from the material at hand. They were also expected to present their results for group discussion at the end of the workshop. During the teamwork phase, the researcher observed and gave instructions on how to read the material if needed, but refrained from directing the team discussions in any way.

For the presentation, the teams formulated nine different improvement ideas linked to different problems presented in the material (Table 1). These problems and corresponding solutions were discussed at the end of the workshop, and the solutions were refined accordingly. After the workshop, the researcher again sent the material to the participants and the management for review and possible additions. 


\begin{tabular}{|c|c|c|}
\hline $\begin{array}{c}\text { Description of the } \\
\text { problem (Initial survey \& } \\
\text { workshop 1) }\end{array}$ & $\begin{array}{l}\text { Description of the solution } \\
\text { (workshop 2) }\end{array}$ & $\begin{array}{l}\text { Description of the metrics, if } \\
\text { any (workshop 4) }\end{array}$ \\
\hline Outdated assets list & Project team for updating lists & $\begin{array}{c}\text { Responsibility of the project } \\
\text { team: constructed on future } \\
\text { date }\end{array}$ \\
\hline $\begin{array}{l}\text { Unclear contracts; quality } \\
\text { standards badly } \\
\text { defined, work orders } \\
\text { unclear, variation in } \\
\text { work prices }\end{array}$ & $\begin{array}{l}\text { Updating of the contracts, } \\
\text { information distribution about } \\
\text { contracts and quality standards }\end{array}$ & $\begin{array}{c}\text { Amount of extra work activities } \\
\text { outside of contracts; either } \\
\text { EUR amounts or \% of yearly } \\
\text { total }\end{array}$ \\
\hline $\begin{array}{l}\text { Schedules for } \\
\text { maintenance activities } \\
\text { late }\end{array}$ & $\begin{array}{l}\text { Coordinated planning of activities } \\
\text { and resourcing with both PPM } \\
\text { sides; GPS tracking devices }\end{array}$ & $\begin{array}{c}\text { Maintenance schedule on time } \\
\text { / late by } x \text { days }\end{array}$ \\
\hline $\begin{array}{l}\text { Insufficient reporting of } \\
\text { work activities }\end{array}$ & $\begin{array}{c}\text { New work reporting system and } \\
\text { reporting instructions }\end{array}$ & $\begin{array}{l}\text { Responsibility of the project } \\
\text { team: Constructed on future } \\
\text { date }\end{array}$ \\
\hline $\begin{array}{l}\text { Insufficient reporting of } \\
\text { extra tasks done on } \\
\text { site. Tracking of costs } \\
\text { difficult }\end{array}$ & $\begin{array}{l}\text { On-site agreements sent as } \\
\text { verification through email }\end{array}$ & $\begin{array}{l}\text { Amount of deviations from the } \\
\text { reporting protocol; yearly } \\
\text { comparison }\end{array}$ \\
\hline $\begin{array}{l}\text { Delayed schedules on } \\
\text { construction sites }\end{array}$ & Project meetings and monitoring & $\begin{array}{c}\text { Amount of sites delayed; } \\
\text { number of days }\end{array}$ \\
\hline $\begin{array}{l}\text { Customer feedback } \\
\text { coming to the wrong } \\
\text { people }\end{array}$ & $\begin{array}{l}\text { Unified customer } \\
\text { service centre }\end{array}$ & None \\
\hline $\begin{array}{l}\text { Insufficient preplanning } \\
\text { of construction } \\
\text { projects }\end{array}$ & $\begin{array}{l}\text { Yearly budget } \\
\text { constructed earlier }\end{array}$ & None \\
\hline $\begin{array}{l}\text { Insufficient coordination } \\
\text { of work activities } \\
\text { between PPM sides }\end{array}$ & Mutual meetings & $\begin{array}{c}\text { Meetings per year compared } \\
\text { to target }\end{array}$ \\
\hline
\end{tabular}

Table 1. Problem-solution Pairs and Corresponding Metrics 


\subsection{Quality costing workshop}

The third workshop for the research project started at the end of March 2008. The 16 selected project participants attended. The plan was to quantify all the QC generated by the problems found in the earlier phases of the project. Costs were to be attributed to particular improvement projects, where applicable. Thus, costs directly incurred by the problem with the improvement project could be used to prioritize the improvement initiatives. These costs were to be evaluated in terms of lost working hours, materials, or other quantifiable costs as evaluated by the employees. Two teams were organized, one for the purchaser and one for the producer. Both teams had eight members and had the option of dividing the given materials among the team.

In the presentation segment of the workshop, the teams reviewed all of the quantified problems. The problems and their associated costs presented ranged from a few thousand euros to hundreds of thousands of euros. Costs comprised estimated lost working hours, equipment costs, lost materials, and some additional specific costs related to particular problems. Adding all of the problem costs together resulted in an estimated total cost for the purchaser equating to $4 \%$ of annual turnover, and $2.5 \%$ on the part of the producer. In both cases, the number does not contain QC coming from prevention or appraisal actions, merely external and internal quality failure costs. 


\subsection{Metrics workshop}

The fourth workshop started in the middle of May 2008. Before the workshop, the researcher had sent the material from the third workshop to the participants and the management of both organizations. The fourth workshop was attended by eight people: the chief executive and three middle managers from both organizations. The aim of this workshop was to pick improvement solutions that had the best potential and create metrics to track the impacts of those solutions. These metrics were anticipated to be both monetary metrics that would help to evaluate the change in $\mathrm{QC}$, and metrics that could help in evaluating the changes in the effects that the target problems were causing for both organizations. The researcher acted as an observer in the workshop and documented the discussions. The workshop started with a joint discussion about those problems and solutions that would have the most potential for implementation. The managers prioritized seven different problems for which brainstorming had produced improvement projects. These seven solutions were slated for implementation in the near future.

The two solutions that were postponed were the establishment of a service centre for phone calls and modification of the budgeting process. The construction of a service centre was postponed following the cost prioritization of the problems, the managers' thoughts on the current most pressing issues, and the resources available to action the solutions. The modification of the budgeting process was postponed as it was deemed unfeasible due to budgetary constraints. The seven prioritized solutions had to be coupled 
with metrics to help the ex post evaluation of the effect of each solution on both organizations.

The eight participants were divided into two teams to discuss predetermined problemsolution pairs. The teams were set up to include participants from both the producer and the purchaser. The teams were asked to present their findings to the workshop participants at the end of the day.

The results of the metrics workshop are summarized in Table 1. The managers left another two of the seven prioritized improvement ideas without metrics, stating that the metrics associated with those projects would be left for the appointed project team to devise. After the presentations, the researcher gathered the materials for transcription. The materials were then sent back to the management of both organizations. This workshop concluded the research project, leaving both organizations to carry out the implementation of the improvement projects chosen at it.

\subsection{Follow-up interviews}

Roughly two years after the project had ended, the researcher went to Organization A and B to conduct follow-up interviews on the case. The interviews were conducted individually with the CEOs of the organizations with the intention of recording the extent to which the results obtained from the study, including the metrics, had been implemented in the organizations and whether the improvement efforts had been 
successful. The interviews were structured interviews as the researcher asked specific questions devised beforehand. The questions posed were designed to obtain information about improvement efforts, quality cost levels, metrics in use, the state of the PPM interface between the two organizations, and the level of commitment to ongoing improvement.

Of the improvement efforts generated in the project, some had been implemented. A new GPS reporting system noted in Table 1 had been implemented as a result of a cooperative project involving both organizations. The main user of the reporting system was Organization B, and real-time data about different work actions was available to both organizations. This solution made it possible to see historical data about vehicle routes and dates, thus clarifying issues around liability. Another improvement effort that had been implemented involved all customer enquiries being directed to one large reception centre where operators logged all calls and determined areas of responsibility. This was one of the solutions postponed in the original metrics workshop. However, it had been decided that interruptions caused by inappropriate calls was serious enough to merit expenditure on a solution.

The organizations had started updating their assets lists immediately after the research project finished, but the work was still ongoing as it was a huge task. Every piece of property had to be catalogued and logged into a database, according to the new rules that had come into effect in the two-year period after the project. 
Problems remained with the digital reporting of extra work agreed to in the field. It seemed that new reporting orders were not always followed, mainly because of the extra workload they caused. Regarding the update of the maintenance contract, it was stated that contracts were still updated continuously on the basis of need and that no lasting contract could be concluded at that point. Therefore, the solution of updated contracts covering all the essential situations was later abandoned, and categorized as merely wishful thinking.

The follow-up interviews were largely consistent on the improvement solutions, probably because almost all of them concerned both organizations. In terms of the metrics, the interviews showed slight differences. The CEO of Organization B stated that the only metric they had implemented was the metric on extra work. The CEO stated that it was the only metric that was 'easy enough to use and informative at the same time'. However, concerning this metric, the CEO of Organization A stated that they had initially considered implementing the metric, but had concerns over its simplicity, as it did not take into account the scale of the extra work. Although it would have been fairly straightforward to add to the metric, a larger problem was found in defining extra work. The CEO of the Organization A told the researcher that 'sometimes additional work can be thought of as inclusive to the main project, while at other times they are considered billable extras'. Both CEOs had similar views on the maintenance tracking metric, indicating that while the idea of tracking the maintenance progress in real-time was a good one, it required mobile devices capable of transmitting data wirelessly, and the organizations did not possess those at the time. These were considered a possibility in the 
future when resources permitted the purchase of such devices. The metric on the reporting protocol was not officially implemented, as deviations from the reporting protocol were evident in everyday work without official tracking. The metric on the delays in construction activities was left unimplemented in both organizations, although the CEO of Organization A remarked that 'Actually, we must look into this in the near future. These interviews are good in a way that they actually revive the issue and push us into considering these things again'. This indicated that there was still some interest in the metrics, at least in Organization A, while in Organization B, the metrics were considered either insufficiently informative or too hard to use. An exception to this was the metric on extra work, which Organization B had implemented.

\section{Discussion and contribution}

While it would be possible to discuss any research approach exclusively in terms of reliability and different dimensions of validity or purely in terms of theoretical linkages and empirical procedures, it is useful to take the research process as the starting point for analysis (see e.g. Labro and Tuomela, 2003). In this way, we can address different methodological aspects, such as theoretical connections, while maintaining a practical focus on conducting interventionist research (see e.g. Ahrens and Dent, 1998). The interventionist approach used in this paper aligns with the idea of the pragmatic notion of truth more than it does with the other research avenues (Malmi and Granlund 2009). Thus, while implemented improvement initiatives are considered to be decision relevant, metrics seem to be largely irrelevant to organizational decision making. 
Westbrook (1995) has discussed the differences between consulting and interventionist research, and noted distinguishing points including constant theory connection and detailed case description. In our study, we have made a theoretical link between project motivation, decision-making influence, and outcome. That is, efficiency-seeking behaviour was evident in our case project, which led to some decision-relevant initiatives that were ultimately used in organizational development. Our case is described as it happened, acknowledging both decision relevant and irrelevant parts of the project. In our study, we have reflected our findings from the project against the literature and tried to describe the case in as much detail as possible, permitting the reader to evaluate and interpret the case. We have taken the method of data collection from MA literature (Malmi et al. 2004), and the data obtained with this method are reflected on the aforementioned discussion presented in the paper.

Carvalho et al. (2012) contend that public organizations mainly seek to legitimize their behaviour to external stakeholders, and it is a view shared by many researchers (Verbeeten 2011, Brignall and Modell 2000). Carvalho et al. (2012, p. 325) ask for 'qualitative analysis to complement their quantitative data and to confirm their hypotheses'. Although a qualitative approach may not be best suited to confirm or reject general findings obtained from quantitative research, our findings do permit some notions to be presented. 
In this study, a quality cost management system was introduced into a purchaserprovider arrangement. Through a series of workshops, problems were identified and their monetary impact was estimated. In addition, improvement initiatives were created to address those issues. Monetary evaluation was used to help in prioritizing those improvement initiatives.

As the initiatives devised and cost data were used to prioritize organizational improvement as well as to carry out the constructed improvements, it can be argued that some of the data created during the project was used in organizational decision making. This meets the criteria for success proposed by both Malmi (1997) and Anderson and Young (1999). At the same time, we have demonstrated a practical solution that was applied in pursuit of efficiency, as expected by the municipality.

However, the metrics developed in the project seem to have been largely abandoned. The reasons were revealed in the follow-up interviews: the metric for the maintenance progress was put on hold because it required mobile devices capable of wireless data transmission. The metric for the reporting protocol, although implemented, had encountered some resistance from the employees. The metric on the construction delays was not implemented in either organization, mainly due to its being insufficiently informative. Use of the metric on extra work differed between organizations. While Organization B had implemented it, Organization A had issues with the metric's simplicity. 
Explanations for the non-use of the metrics are numerous; nevertheless, the lack of action on the metrics is largely obvious. However, this does not necessarily signal legitimationseeking behaviour. Those metrics that were not implemented either lacked functionality, failed to provide enough information, or were not topical at the time. Thus, the metrics, for the most part, did not address the practical concerns of the managers.

User involvement in the project is likely to ensure that development topics centre on organizationally important issues, thereby increasing the expected practical relevance of the project's outcomes. However, since the organizations have no way of knowing in the design phase of the project what amount of resources the constructed improvement initiatives or the metrics will absorb, it may be that implementation-related problems concerning the metrics were underestimated during this stage. In addition, our case evidence seems to indicate that the management of organizations A and B overestimated the future functionality of the metrics in the project start-up considerations. This is because there is no clear indication of the form these metrics will take until personnel of the organization have brainstormed them. Some examples of similar results concerning the metrics were offered in the studies by Adolfsson and Wikström (2007) and ter Bogt (2008), in which quality systems did not address economic concerns or projects proved less practical than anticipated.

The form of the empirical data does not permit an assessment of whether a legitimationseeking motive could also explain why the metrics were designed but ultimately not used. However, as Järvinen (2006) notes, the initiative for implementation may be intra- 
organizational or extra-organizational, and the rationale is a combination of economic argumentation and institutional pressure. In our case, the organizations were in a situation in which the municipality was expecting improved efficiency, which may have created an institutional pressure and extra-organizational influence constituting a form of coercion on the two organizations to pursue improvements in efficiency. Kantola and Järvinen (2012) have also noted this in their study; institutional pressures from the municipality created a situation where the organizations were forced into efficiency-seeking behaviour.

Therefore, it is possible that the organizations in our case might have sought efficiency gains and at the same time, to legitimize themselves through initiating a project targeting efficiency. Nevertheless, the organizations were free to choose the methods for efficiency improvement by themselves. This may influence the outcomes of the chosen project, as coercive isomorphism may result more often in legitimation-seeking behaviour when organizations are forced to conform to pre-existing models.

The results from the project, excluding the metrics, can be considered relevant: the constructed initiatives and fishbone diagrams contributed to an understanding of the decision-making situation, and the cost data generated in the project to information on the consequences of a given course of action. The organizations were able to prioritize improvement initiatives with the help of the cost information generated. Instrumental and conceptual relevance are therefore evident in the project. As noted, the existence of cognitive legitimacy cannot be verified in our study, although the directive issued by the 
municipality may have created institutional pressure to integrate efficiency-seeking models into organizational processes.

To sum up, as discussed earlier, we acknowledge that legitimation-driven implementation may be relevant: an organization may implement a certain technique with the ex-ante goal of legitimizing itself in front of external stakeholders, for example, to secure future funding from the municipality. We also agree with Järvinen (2006) that economic reasons and legitimation-seeking concerns may both influence any cost management project considerations. However, we caution against labelling inaction in the cost management implementation as predominantly legitimation-seeking behaviour. As noted, the possible underestimation of implementation-related problems in the design phase, a lack of functionality, or decision-irrelevance are also possible explanations for an adopted tool remaining unused.

In this paper, we have suggested one MA technique that evidently led to actual decisions, although some measures of the technique were not implemented. The improvement initiatives largely demonstrated instrumental and conceptual relevance, while the metrics were mostly deemed uninformative or lacking in functionality. This resulted in most of the metrics being unimplemented. Legitimative relevance may have been a background motive together with efficiency-seeking reasons for the organizations to initiate cost management efforts. Our case presents evidence where practical solutions were found and implemented into the organizational life. This is in contrast with the recent notions 
that public sector organizations tend only to legitimate themselves through the adoption of various cost management measures.

Finally, Malmi and Granlund (2009) point out that the success, or relevance, of a given technique is dependent on the social and organizational context in which it is found. Our findings are inevitably tied to the public sector, although our proposition can be tested in different contexts or public sector functions. It would be interesting to conduct a research study with an initial survey to find cost management changes resulting in actual decision-making, then perhaps to interview the employees in those organizations. This would enhance the knowledge of the techniques that do lead to the use of new information. 


\section{REFERENCES}

Adolfsson, P. and E. Wikström (2007), 'After Quantification: Quality Dialogue and Performance', Financial Accountability \& Management, Vol. 23, No. 1, pp. 73-89.

Ahrens, T. and J. F. Dent (1998), 'Accounting and Organizations: Realizing the Richness of Field Research', Journal of Management Accounting Research, Vol. 10, pp. 1-39

Anderson, S. and S. Young (1999), 'The Impact of Contextual and Process Factors on the Evaluation of Activity Based Costing Systems'Accounting, Organizations and Society, Vol. 24, No.7, pp. 525-559.

Ansari, S., J. Bell, T. Klammer and C. Lawrence (1997), 'Measuring and Managing Quality Costs', Management Accounting - A Strategic Focus, a Modular Series (New York: McGraw-Hill).

Argyris, C., R. Putnam and D. McLain Smith (1985), Action Science (Jossey-Bass San Francisco, California).

Arnaboldi, M. (2013), 'Consultant-Researchers in Public Sector Transformation: An Evoking Role', Financial Accountability \& Management, Vol. 29, No. 2, pp. 140-160. Ashforth, B. E. and B.W. Gibbs (1990), 'The Double-edge of Organizational Legitimation', Organization Science, Vol. 1, pp. 177-194.

Atkinson, H., J. Hamburg and C. Ittner (1994), Linking Quality to Profits: Quality-Based Cost Management (ASQ Quality Press, Milwaukee, WI, USA).

Baard, V. (2010), 'Critical review of interventionist research', Qualitative Research in Accounting \& Management, Vol. 7, No. 1, pp. 13-45. 
Brignall, S. and S. Modell (2000), 'An Institutional Perspective on Performance Measurement and Management in the New Public Sector', Management Accounting Research, Vol. 11, No. 3, pp. 281-306.

Carvalho, J., P. Gomes and M.J. Fernandes (2012), 'The Main Determinants of the Use of the Cost Accounting System in Portuguese Local Government', Financial Accountability \& Management, Vol. 28, No. 3, pp. 306-334.

CIMA (2005). CIMA Official Terminology 2005 edition, CIMA (Oxford).

Crosby, P.B. (1979), Quality Is Free (Mentor, New York).

DiMaggio, P.J. and W.W. Powell (1983), 'The Iron Cage Revisited: Institutional Isomorphism and Collective Rationality in Organizational Fields', American Sociological Review, Vol. 48 (April), pp. 147-160.

Dowling, J. and J. Pfeffer (1975), 'Organizational Legitimacy: Social Values and Organizational Behavior', Pacific Sociological Review, Vol. 18, pp. 122-136.

Eisenhardt, K. (1989), 'Building Theories from Case Study Research', Academy of Management Review, Vol. 14, No.4, pp. 532-550.

Gryna, F., R. Chua, and J. DeFeo (2007), Juran's Quality Planning and Analysis for Enterprise Quality, 5th edn. (McGraw-Hill, New York).

Hitt, M.A. (2005), 'Management Theory and Research: Potential Contribution to Public Policy and Public Organizations', Academy of Management Journal , Vol. 48, No. 6, pp. 936-966.

Hood, C. (1995), 'The "New Public Management" in the 1980s: Variations on a Theme', Accounting, Organizations and Society, Vol. 20, No. 2/3, pp. 93-109. 
Hoozee, S. and W. Bruggerman (2010), 'Identifying Operational Improvements During the Design Process of a Time-Driven ABC System: The Role of Collective Worker Participation and Leadership Style', Management Accounting Research, Vol. 21, No. 3, pp.185-198.

Horngren, C.T., S.M. Datar, G. Foster, M. Rajan and C. Ittner (2009), Cost Accounting: A Managerial Emphasis (13th ed., Pearson International Edition, Prentice Hall).

Hyvönen, T. and J. Järvinen (2006), 'Contract-Based Budgeting in Health Care: A Study of the Institutional Processes of Accounting Change', European Accounting Review, Vol. 15, No. 1, pp. 3-36.

Ishikawa, K. (1985), What is Total Quality Control? The Japanese Way (Prentice-Hall International, London)

Ittner, C.D. (1999), 'Activity-Based Costing Concepts for Quality Improvement', European Management Journal, Vol. 17, No. 5, pp. 492-500.

Ittner, C.D. and D.F. Larcker (1996), 'Measuring the Impact of Quality Initiatives on Firm Financial Performance', Advances in the Management of Organizational Quality, Vol. 1, pp. 1-37.

Johansson, T. and S. Siverbo (2009a), 'Explaining the Utilization of Relative Performance Evaluation in Local Government: A Multi-Theoretical Study Using Data from Sweden', Financial Accountability \& Management, Vol. 25, No. 2, pp. 197-224. — - (2009b), 'Why is Research on Management Accounting Change Not Explicitly Evolutionary? Taking the Next Step in the Conceptualisation of Management Accounting Change', Management Accounting Research, Vol. 20, Issue 2, pp. 146-162. 
Järvinen, J. (2006), 'Institutional Pressures for Adopting New Cost Accounting Systems in Finnish Hospitals: Two Longitudinal Case Studies', Financial Accountability \& Management, Vol. 22, No. 1, pp. 21-46.

Jönsson, S. and K. Lukka (2005), 'Doing Interventionist Research in Management Accounting: GRI-Rapport 2005:6', Handelshögskolan vid Göteborgs universitet.

— - (2007), 'There and Back Again: Doing Interventionist Research in Management Accounting', in A. Hopwood, M. Shields and C. Chapman (eds.), The Handbook of Management Accounting Research (Elsevier).

Juran, J. M. (1989), Juran on Leadership for Quality (The Free Press, New York).

Kallio, O., J.P. Martikainen, P. Meklin, T. Rajala and J. Tammi (2006), 'Kaupungit Tilaajina ja Tuottajina: Kokemuksia ja Näkemyksiä Jyväskylän, Tampereen ja Turun Toimintamallien Uudistushankkeista', Tampereen yliopisto, 2006.

Kantola, H. and J. Järvinen, (2012), 'Analysing the Institutional Logic of Late DRG Adopters', Financial Accountability \& Management, Vol. 28, No. 3, pp. 269-285

Kaplan, R. (1998), 'Innovation Action Research: Creating New Management Theory and Practice', Journal of Management Accounting Research. Vol. 10, pp. 89-118

Kasanen, E., K. Lukka and A. Siitonen (1993), 'The Constructive Approach in Management Accounting Research', Journal of Management Accounting Research, Vol. 5, pp. 241-264.

Labro, E., Z. Degraeve and F. Roodhooft (2005), 'Constructing a Total Cost of Ownership Supplier Selection Methodology based on Activity Based Costing and Mathematical Programming', Accounting \& Business Research, Vol. 35 No. 1, pp. 409-22. 
Labro, E. and T.-S. Tuomela, (2003), 'On Bringing More Action Into Management Accounting Research: Process Considerations Based on Two Constructive Case Studies', European Accounting Review, Vol. 12, No. 3, pp. 409-442.

Lapsley, I. (1999), 'Accounting and the New Public Management: Instruments of Substantive Efficiency or Rationalizing Modernity?', Financial Accountability \& Management, Vol. 15, No. 3/4, pp. 201-207.

Lapsley, I. and R. Oldfield (2001), 'Transforming the Public Sector: Management Consultants as Agents Of Change'. European Accounting Review, Vol. 10, No. 3, pp. 523-543.

Lawrence, T.B. and R. Suddaby (2006), 'Institutions and Institutional Work', in S.R. Clegg, C. Hardy, T.B. Lawrence and W.R. Nord (eds.), The Sage Handbook of Organization Studies (2nd ed., Sage, Thousand Oaks, CA)

Lewin, K. (1946), ‘Action Research and Minority Problems', in G.W. Lewin (ed.) Resolving Social Conflicts. Selected Papers on Group Dynamics (Harper \& Row, New York).

Lounsbury, M. (2007), 'A Tale of Two Cities: Competing Logics and Practice Variation in the Professionalizing of Mutual Funds', Academy of Management Journal, Vol. 50, No. 2, pp. 289-307.

Lukka, K. (2005), 'Approaches to the Case Research in Management Accounting: the Nature of Empirical Intervention and Theory Linkage', in Accounting in Scandinavia -The Northern Lights, Liber \& Copenhagen Business School Press. (2006), 'Interventionist research', Journal of Social Issues, November, p. 36. 
_ _ (2007), 'Management accounting change and stability: loosely coupled rules and routines in action', Management Accounting Research, Vol. 18, pp. 76-101.

Lukka, K. and E. Kasanen (1995), 'The problem of generalizability: anecdotes and evidence in accounting research', Accounting, Auditing and Accountability Journal, Vol. 8, No. 5, pp. 71-90.

Malmi, T., P. Järvinen and P. Lillrank (2004), ‘A Collaborative Approach for Managing Project Cost of Poor Quality', European Accounting Review, Vol. 13, No. 2, pp. 293317.

Malmi, T. (1997), ‘Towards Explaining Activity-Based Costing Failure: Accounting and Control in a Decentralized Organization', Management Accounting Research, Vol. 8, No. 4, pp. 459-480.

Malmi, T and M. Granlund (2009), 'In Search of Management Accounting Theory', European Accounting Review, Vol. 18, No. 3, pp. 597-620.

McChelry, S., J. McKendrick and T. Rolfe (2007), ‘Activity-Based Management Systems in Higher Education', Public Money \& Management, November, pp. 315-21.

Meyer, J. W. and B. Rowan (1991), 'Institutionalized Organizations: Formal Structure as Myth and Ceremony', in W. W. Powell and P. J. DiMaggio (eds), The New Institutionalism in Organizational Analysis, pp. 41-62 (University of Chicago Press, Chicago).

Modell, S. (2005), 'Triangulation between Case Study and Survey Methods in Management Accounting Research: An Assessment of Validity Implications', Management Accounting Research, Vol. 16, No. 2, pp. 231-254. 
Modell, S. (2009), 'Institutional Research on Performance Measurement and Management in the Public Sector Accounting Literature: a Review and Assessment', Financial Accountability \& Management, Vol. 25, No. 3, pp. 277-303.

Moll, J. and Z. Hoque (2008), 'New Organizational Forms and Accounting Innovations', Journal of Accounting \& Organizational Change, Vol. 4, No. 3, pp. 243-269.

Morgan, G and L. Smircich (1980), 'The Case for Qualitative Research', The Academy of Management Review, Vol. 5, No. 4, pp. 491-500.

Mouritsen, J., H.T. Larsen, and A. Hansen, (2002), 'Be critical! Critique and Naiveté Californian and French Connections in Critical Scandinavian Accounting Research', Critical Perspectives in Accounting, Vol. 13, No. 4, pp. 497-513.

Mättö, T. (2012), 'Implementation of Quality Cost Management Tool in a Dyadic Purchaser-Provider Relationship Context'. Dissertation. Jyväskylä Studies in Business and Economics 114.

Nicolai, A., and D. Seidl (2010), 'That's Relevant! Different Forms of Practical Relevance in Management Science', Organization Studies, Vol. 31, No. 9/10, pp. $1257-1285$.

Oliver, C. (1991), 'Strategic Responses to Institutional Processes', Academy of Management Review, Vol. 16, No. 1, pp. 145-179.

Rynes, S.L. and D.L. Shapiro (2005), ‘Academy of Management Journal Editor’s Forum: Public Policy and the Public Interest: What if We Mattered More?', Academy of Management Journal, Vol. 48, No.6, pp. 925-927.

Schein, E. (1993), 'Legitimating Clinical Research in the Study of Organizational Culture', Journal of Counseling \& Development, Vol. 71, No. 6, pp. 703-708. 
Schiffauerova, A. and V. Thomson (2006), 'A Review of Research on Cost of Quality Models and Best Practices', International Journal of Quality \& Reliability Management, Vol. 23, No. 6, pp. 647-669.

Seokhin, K. and B. Nakhai (2008), 'The Dynamics of Quality Costs in Continuous Improvement', International Journal of Quality \& Reliability Management, Vol. 25, No. 8, pp. 842-859.

Suchman, M. (1995), 'Managing Legitimacy: Strategic and Institutional Approaches', Academy of Management Review, Vol. 20, No. 3, pp. 571-610.

Ter Bogt, H.J. (2008), 'Management Accounting Change and New Public Management in Local Government: a Reassessment of Ambitions and Results - an Institutionalist Approach to Accounting Change in the Dutch Public Sector', Financial Accountability \& Management, Vol. 24, No. 3, pp. 209-241.

Ter Bogt, H.J. and J.G. Van Helden (2011), 'The Role of Consultant-Researchers in the Design and Implementation Process of a Programme Budget in a Local Government Organization', Management Accounting Research, Vol. 22, No. 1, pp. 56-64.

Van Aken, J. (2004), 'Management Research Based on the Paradigm of the Design Sciences: The Quest for Field-Tested and Grounded Technological Rules', Journal of Management Studies. Vol. 41, No.2, pp. 219-246.

Van Helden, G.J. (2005), 'Researching Public Sector Transformation: The Role of Management Accounting', Financial Accountability \& Management, Vol. 21, No.1, pp. 99-133. 
Van Helden, G.J. and D. Northcott (2010), 'Examining the Practical Relevance of Public Sector Management Accounting Research', Financial Accountability \& Management, Vol. 26, No. 2, pp. 213-240.

Van Helden, G.J., H. Aardema, H.J. Ter Bogt and T.L.C.M. Groot (2010), 'Knowledge creation for practice in public sector management accounting by consultants and academics; preliminary findings and directions for future research', Management Accounting Research, Vol. 21, pp. 83-94.

Verbeeten, F. (2011), 'Public Sector Cost Management Practices in the Netherlands', International Journal of Public Sector Management, Vol. 24, No. 6, pp. 492-506.

Westbrook, R. (1995), 'Action research: a new paradigm for research in production and operations management', International Journal of Operations and Production Management, Vol. 15, No. 12, pp. 6-20. 


\section{APPENDIX}

\section{Fishbone diagram example}

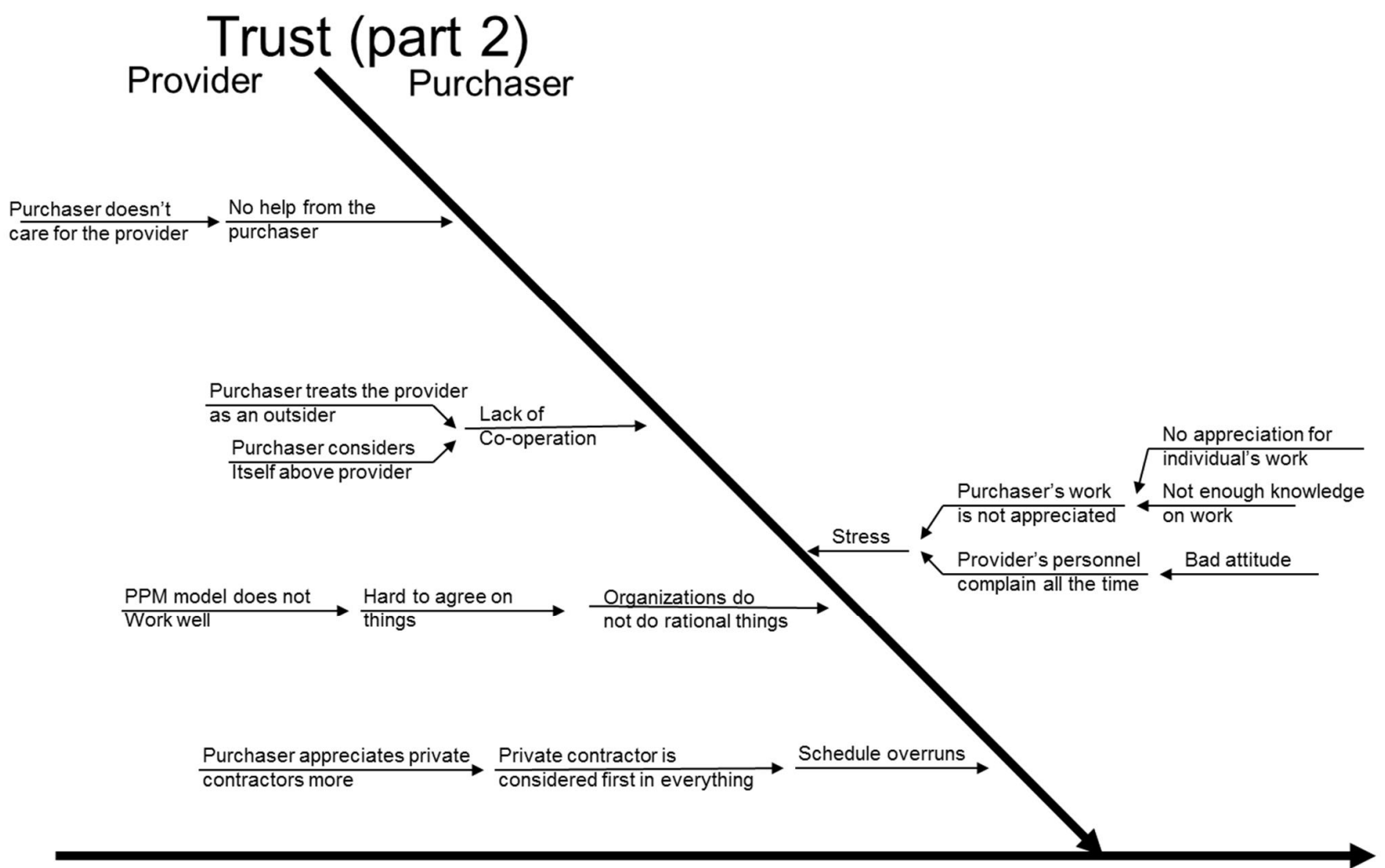

